\title{
NOTES ON THE GENUS ANABAENOPSIS
}

\author{
Wm. Randolph Taylor \\ (Received for publication December 16, 1931) ${ }^{1}$
}

\section{INTRODUCTION}

Two years ago there were sent to the writer for study, through the kindness of Dr. Eduardo Quisumbing of the Bureau of Science, Manila, P. I., a few samples of phytoplankton. While some of the material has not proven of notable character, two samples showed representatives of the relatively recently recognized genus Anabaenopsis (Wołoszyńska) V. Miller $(7,10)$, not attributed to the Philippines, and so worthy of special ttention.

The material for both samples came from Sampaloc Lake, in the town of San Pablo, Laguna Province, Luzon Island, in I929. One sample, from the open lake, contained what appeared to be two similar species of short filaments; the other had scattered filaments of these species but was dominated by a third which formed helixes of considerable length. They are reported to appear as abundant autumnal waterbloom at intervals of $3^{-4}$ years, producing a very offensive odor.

Several species of Anabaenopsis have been described: A. tanganyikae (G. S. West) V. Miller and $A$. circularis (G. S. West) V. Miller from Africa $(7,9) ; A$. circularis var. javanica (Wolos.) Elenkin and A. Raciborskii (Wołos.) Elenkin from Java (3, Io); A. Elenkinii V. Miller, A. Arnoldii Aptek., and A. Arnoldii var. recta Roll from Russia $(\mathrm{I}, 7,8)$; and attributed to this genus also $A$. hispanica Gonz.-Guerr., A. hispanica var. luteola Gonz.-Guerr., and A. Cuatrecasasii Gonz.-Guerr. from Spain and Morocco $(5,6,6 \mathrm{a})$. The geographical range of the genus is seen to be wide. The general concept seems to call for a truly phytoplankton organism with rather rigid trichome, straight or curved increasingly to a helix of varying character; heterocysts occur at each end of the trichome and the relatively smooth spores are spherical or oval and generally remote from the heterocysts in position. The species $A$. hispanica and $A$. Cuatrecasasii depart somewhat from the sharp genus concept in that they have flexuous trichomes with spores, in one case spiny, adjacent to the heterocysts and apparently are not truly phytoplankton organisms. They are reminiscent of the plants which K. M. Drew (2) reported, she considering that hers were well known species of Cylindrospermum with heterocysts, and sometimes adjacent spores, at both ends of the trichomes. The Spanish plants do not urgently concern us, since they do not resemble the Philippine plants, so they will not be

${ }^{1}$ Papers from the Department of Botany, University of Michigan, No. 360. 
considered further here. The remainder fall naturally into two groups: in one the trichomes are relatively short, straight or in $\mathrm{I}-3$ coils, and sharply contracted at the cell ends or moniliform, with short rounded heterocysts; this includes $A$. circularis, $A$. Elenkinii and $A$. Arnoldii. The others, A. tanganyikae and $A$. Raciborskii, have longer or more extensively coiled trichomes little or not constricted, and with oval or elongated heterocysts. Both of these groups are represented in Africa, in Java, and in the Philippines. The finding of three forms in Sampaloc Lake, and the resemblance of two of these to Tanganyika species, necessarily led to a consideration of the exact morphology of the original African types. Through the great kindness of Professor F. E. Fritsch portions of three original samples were secured from Dr. W. A. Cunnington for study by the writer. Material of Anabaenopsis circularis (Anabaena flos-aquae var. circularis G. S. West) was sufficiently abundant in two of these, and the writer was able to come to a definite opinion respecting that species. Less information was secured regarding Anabaenopsis tanganyikae (Anabaena tanganyikae G. S. West), as trichomes were excessively rare.

A close inspection of the figures given by West (9, Pl. Io, figs. 2a-e) of his Anabaena flos-aquae var. circularis may well awaken suspicion as to the specific unity of the material with which he was dealing. Figure $2 b$ has markedly compressed-spherical cells of greater diameter than shown by the other figures, where the cells, except after division, are much longer. Then one notes that figures $2 a$ and $2 c$ have rounded heterocysts while those of $2 d$ and $2 e$ have oval ones. These are all features of diagnostic value in the Nostocaceae, and considerable variability within a species calls for careful explanation. West's description of his new variety allows for the variation in shape of the vegetative cells and for considerable variation in diameter of the heterocyst, but is so brief, and the figures are so few and so small, that only a careful re-examination of the original material could set at rest the doubts awakened by the Philippine associations of species and encouraged by the variations in the figures cited.

It appears that, of the three Anabaenopses in the Philippine material, one (resembling $A$. tanganyikae) is not to concern us immediately. The other two rather resembled, the one figures $2 a$ and $2 c$ of West, and the other figure $2 b$. As the writer had satisfied himself that these two Philippine species were distinct, and had prepared diagnoses of them with what appeared to be satisfactorily contrasted characters, the differences between West's figures impressed him sharply immediately he attempted to decide which of the Philippine plants should be identified with the Tanganyika species. It was obvious that, if different, both could not be identified with West's concept, and even if that with longer cells was called $A$. circularis and the other $A$. circularis var. javanica, no stable decision had been reached, because of the variation between West's figures, for the differences between them were greater than those between his figure $2 b$ and the characters of the Javanese variety. 


\section{African Material}

Selecting the Tanganyika material from station 160 (Chamaluki, I5 Nov. 1904) as most abundant, a very careful series of drawings was made of all types of trichomes referable to Anabaenopsis, in the formalin preservative accompanying them. At first trouble was anticipated in quickly distinguishing Anabaena flos-aquae and the variety circularis, sensu West's figure $2 b$, but it was soon found that the more compressed cells, paired young intercalary heterocysts, and differences in diameter sufficiently facilitated recognition. The preliminary drawings sorted out readily into three classes as suggested by the groups under West's figure 2 , and suites of measurements and further drawings were made. The two other samples confirmed the observations made on that from station I60. As a result three plants may be defined:

Anabaenopsis circularis (G. S. West) V. Miller emend. (Pl. XXXIX, figs. $5^{-10}$ ).

Trichomes short, curved into a nearly complete circle or coiled into a short spiral of $\mathrm{I}-\mathrm{I} \frac{1}{3}$ rarely (and usually just before fragmentation between two young heterocysts) 2 or 3 turns of $40^{-}-50 \mu$ in diameter; trichomes $4.7-(5.3)^{2}-6.5 \mu$ in diameter, cells cylindrical or slightly barrel-shaped with moderately rounded ends, compressed at plane of contact, generally about $7.5 \mu$ (I.4 diameters) long, but reaching Io.6 $\mu$ in average maximum length; color of contents indeterminable, texture slightly granular; heterocysts terminal at both ends of the trichome, slightly elongated, granule small but usually visible, diameter of heterocyst $5.6-(6.5)-7.5 \mu$, length $6.5-(7 . I)-8.4 \mu$ (ratio I : I.09), pale straw-colored or colorless; spores not seen.

This is associated with West's original varietal name, first because it alone is in close conformity with the measurements for trichome and heterocysts which he specifies, and second because it was the most abundant of the three forms, in so far as the samples in the writer's hands were concerned. As it seems necessary to designate one of them as the type of Anabaenopsis circularis (Anabaena flos-aquae var. circularis) this is, for the reasons given, the one selected. It is unfortunate that his measurements alone can be used to guide in the selection, but his description of cell form and selection of figures was apparently carefully prepared to cover all types. West's figures $2 a$ and $2 c$ seem to correspond to this description. Upon comparison with $A$. Elenkinii we find few features which can be cited in distinction from the Russian plant. Miller (7) offers characters which give little in trichome diameter or length to distinguish between them, but the cell shapes differ. In the heterocysts we have a difference also, namely that those in $A$. Elenkinii are spherical and perhaps a bit smaller on the average than the slightly oval ones of $A$. circularis.

${ }^{2}$ Where measurements are given thus: $4.7-(5 \cdot 3)-6.5$ : the middle italicized figure represents an average from several measurements, and ratios are calculated, when given, between the average length and breadth figures. 
Anabaenopsis Cunningtonii n.sp. (Pl. XXXIX, figs. $\mathrm{r}-4$ ).

Trichomes short, IIO-333 $\mu$ or probably somewhat longer, averaging about I $65 \mu$, straight or occasionally curved; trichomes $2.2-(3.6)-3.8 \mu$ in diameter, cells cylindrical or slightly barrel-shaped with moderately rounded ends compressed at plane of contact, generally about I I.o $\mu$ (3-4 diameters) long, but reaching $\mathrm{I} 6.4 \mu$ in average maximum length before division; color of contents indeterminable, texture slightly granular; heterocysts terminal at both ends of the trichome, oval or slightly obovate, somewhat flattened at contact with the trichome and usually with visible granule, $4.7-(5.8)-6.6 \mu$ in diameter, $6.6-(7.9)-10.3 \mu$ long (ratio of I : I.36); trichome segments quickly separating with sufficient maturation of the heterocysts, which are formed in pairs; spores not seen.

This species is distinguished from the preceding by its straight trichomes with longer cells and more oval heterocysts. Except for these features it would be much harder to distinguish from $A$. circularis than either from the following type. Only with misgiving has the writer assigned any curved filaments to this species; care should be taken in measuring heterocysts not to measure the rounder shrunken content rather than the longer firm but hyaline wall. West's figure $2 e$ (and possibly $2 d$ ) corresponds to this description.

Anabaenopsis Arnoldil Aptek., fa. (African form) (PI. XXXIX, figs. I I-I4).

Trichomes short, curved to $270^{\circ}$ or a complete circle, or into a spiral of I-I $\frac{1}{3}$, rarely to 3 turns of $50-65 \mu$ in diameter; trichomes $7 . I-(7.7)-8.5 \mu$ in diameter, cells compressed spherical to short barrel-shaped before division, length generally somewhat shorter than the diameter but from incidence of cells soon to divide averaging $8.3 \mu$ long; color indeterminable, texture obscurely but coarsely granular; heterocysts subspherical, with thin membrane and granule at base, $6.6-(g .8)-10.3 \mu$ in diameter $8.5-(0.4)-10.3 \mu$ long (ratio I : 0.96 ); trichome segments soon separating between the paired young heterocysts; spores not seen.

This is the most easily distinguished of the three species the writer believes were confused in the original Anabaena flos-aquae var. circularis, by reason of its large, nearly round cells and heterocysts. It is very close to Anabaenopsis Arnoldii, differing in having shorter coils of trichome and larger, spherical rather than short oval heterocysts at maturity. Neither of these is enough to justify specific, and probably not even varietal, separation, nor does the difference in diameter of the coils greatly signify. The variety recta of $A$. A rnoldii is somewhat smaller than the type, as well as straighter, and otherwise as well as in its straightness differs more from it than does the Tanganyika plant described above. The writer would associate West's figure $2 b$ with this species.

Aptekarj (I) stresses the paired intercalary heterocysts seen in his plant as a feature to distinguish it from the other Anabaenopsis species; this is not a character that can be thus applied. It appears that, in Anabaenopsis, the heterocysts are formed in pairs by the unequal subdivision of 
two vegetative cells, each cutting off a smaller portion on the adjoining ends. These two portions then enlarge and mature in contact into the characteristic heterocysts of the species. Ordinary division of vegetative cells occurs near the middle of the parent cell. Formation of heterocysts is well shown in $A$. Cunningtonii (Pl. XXXIX, figs. I, 4), in A. circularis (P1. XXXIX, figs. 6, 8, 10, 9, 5), in $A$. Arnoldii fa. (P1. XXXIX, figs. I I, I2, I4), and the well known constrictive cell division in many of the figures. This is not a new observation (I).

If, now, the Javanese $A$. circularis var. javanica be compared with $A$. Arnoldii, it will be seen that in form of cells and in size it is more closely related to that species than to $A$. circularis in the restricted sense. In fact, if $A$. Arnoldii be maintained distinct from $A$. circularis, so must be the Javanese plant. On comparison of the measurements of these two $(A$. Arnoldii and the var. javanica), it will be seen that the vegetative cell characters will hardly serve to distinguish them, and only the heterocyst size, particularly in that the heterocysts are smaller or larger than the average trichome diameter, serve to separate them. Consequently, it seems more in conformity with the obvious morphological similarities to associate with $A$. Arnoldii the variety javanica (Wolos.) n. comb., which differs from the species in having slightly more slender trichomes, smaller heterocysts and larger spores.

Finally, referring to the character which West uses, of the single large "pseudovacuole" in the vegetative cells of his plants, the writer would report having seen these structures, and would doubt, from the inconstancy of their position, size, number and even presence, that they are sufficiently reliable to afford a good diagnostic character. Most frequently they are indeed single, but occur to 5 or more in a cell, and as now observed after over 25 years in formaldehyde, do not present the aspect of pseudovacuoles.

\section{Philippine Material}

Turning now to the Philippine material, supplied to the writer dried on glass slips, and studied in distilled water, the most striking of the forms from Sampaloc Lake is to be described as new under the name:

ANABAENopsis philippinensis n.sp. (Pl. XL, figs. I-7).

Trichomes elongated, spirally coiled in few to generally several (8-I2) turns, of $12-25 \mu$ in diameter, or very long and becoming loosely to closely entangled, when some parts usually retain a spiral disposition; diameter of trichomes I.9-(3.3)-3.8 $\mu$, fairly uniform; cylindrical cells faintly or generally not constricted at the ends, the septa very indistinct, but length at least twice the diameter; contents very pale bluish-green, very slightly granular, without pseudovacuoles; heterocysts terminal at each end of the trichome, $2.6-(3.5)-3.8 \mu$ in diameter, $7.5^{-}(0.4)-\mathrm{I} 3.2 \mu$ long (ratio I : 2.7 ), rounded conical, tapering from close to the base towards the rounded apex, straight to more of ten asymmetrical or curved, the membrane very pale straw-colored, thin, hardly thickened even at the juncture with the trichome, and basal granule absent; spores not seen. 
From the richness of the dried mount, this plant apparently was not as abundant as the other two species, and was found more along the shore than in the open water. Plate XL, figures $I-7$, shows its characteristics adequately; the more involved tangles of the very long trichomes, or chains of trichomes, were not drawn, but transitions from regular coils (figs. I, 4) toward less regular, loose loops (figs. 3, 5) are shown. Except semidiagrammatically in figure $\mathbf{I}$, no attempt was made to show the position of the septa, which were ill defined. The curved heterocysts show best in figures 2 and 7 . This plant falls into the group with $A$. tanganyikae and A. Raciborskii. Its elongated heterocysts distinguish it at once from the former, and relate it to the Javanese A. Raciborskii. However, they greatly exceed those of the latter species (which are $2.0-2.5 \mu$ in diameter and 5-6 $\mu$ long) since they reach a length of $\mathrm{I} 3.2 \mu$ and also are curved. The trichome, however, is but a little more slender, contrasting its I.9-3.8 $\mu$ with the $4.0 \mu$ of $A$. Raciborskii, which would be slight difference were it not associated with that between the highly coiled trichomes of $A$. philippinensis and the straight or sparingly coiled trichomes of the Javanese plant. In view of what we know of the two collections, it is clearly desirable to treat the Philippine plant as distinct from its more southern relative, and from the African species. Respecting the latter, however, it may be noted that in a single trichome seem by the writer, the heterocysts were $\mathbf{5 . 5}$ and $6.0 \mu \mathrm{long}$, and 2.0 and $2.5 \mu$ in diameter, somewhat more slender than West (9) cites; the trichome was $2.0-2.5 \mu$ in diameter, and the cells seemingly much longer than described; but the walls were indistinct.

Out in the central portions of Sampaloc Lake the phytoplankton was quite different, though still of Anabaenopsis. At first the writer was puzzled to account for the variability of the trichomes, but he finally decided that two organisms were intermixed. Of these the first in abundance is recognized as:

Anabaenopsis Arnoldi Aptek. fa. (Philippine form) (P1. XL, figs. I6-22).

Trichomes short, rarely straight or arcuate, usually coiled in $\mathbf{I}$, rarely 2 flat or spiral turns of $30-65 \mu$ diameter; the nearly moniliform trichomes $7.5^{-(8.7)-9.4 \mu}$ in diameter, cells truncate spherical to truncate oval, equal or a little shorter or longer than broad, to decidedly longer just before division; contents pale blue-green, distinctly granulate, with pseudovacuoles; heterocysts terminal at both ends of the trichome, truncate spherical to slightly truncate ovoid, 5.6-(7.9)-9.8 $\mu$ in diameter, $7.5-(7.9)-9.4 \mu$ long (ratio I : I), nearly colorless, the wall firm, moderately thickened especially on the distinctly flattened end of contact with the trichome, but no granule in evidence; spores intercalary, not seen close to the heterocyst, quickly isolated by fracture of the trichome on one or both sides of the spherical or generally oval spore, 8.I-I2.0 $\mu$ in diameter, I2.0-I6.0 $\mu$ long, wall smooth, rather thin, colorless or faintly straw-colored.

This Anabaenopsis was very abundant, and the most richly represented of the three, judging from the heavily strewn mount. Its relatives are 
A. Elenkinii, A. circularis and A. Arnoldii. The shape of the cells associates it inescapably with the latter species. On comparison of the measurements, it will be found that the plants of the present material show trichomes which probably exceed the type of $A$. Arnoldii in average diameter, and on the whole seem to have somewhat longer cells; the var. javanica and the African representative show more slender trichomes, the former seeming somewhat less deeply constricted. Taking the heterocysts, we find that they are probably on the average larger than the type and, by definition, larger than var. javanica, but notably smaller than the African form. Taking the spores, we find that those of the Philippine plant are intermediate between the type and the var. javanica, but relatively more slender. Other and minor differences, such as apparent absence of basal heterocyst granules, could be noted, but the writer is inclined to consider all of the differences of quite secondary specific value, and the establishment of varieties premature. In Plate XL figures $16-22$ represent the Philippine form. In figure I 7 at the lower portion the trichome is probably in process of division, and about to form a pair of heterocysts. It appears that the daughter trichomes separate promptly in this material, but the unequal size of the heterocysts on the two ends of several of the trichomes (figs. 17,20 ) probably is to be recognized as indicating unequal age. Spores are shown in figures 21,22 , and are generally isolated by breaking of the trichome from one or both sides. The writer does not consider that they are ordinarily formed terminally in this material.

The third species of Anabaenopsis in the Philippine samples was principally found mixed in relatively small proportion with the last, recognizably different as more slender and less granular in aspect, with relatively longer cells. It may be described:

ANABAEnopsis luzonensis n.sp. (Pl. XL, figs. 8-I5).

Trichomes short, occasionally straight or curved, generally coiled in one, rarely 2 , flat or spiral turns of $28-45 \mu$ diameter, but trichome segments frequently adhering by the terminal heterocysts to form helixes of a few irregular turns; trichomes $5.2-(6.4)-7.5 \mu$ in diameter, cells barrel-shaped, distinctly narrowed from the center toward the ends to $3 / 4-2 / 3$ their full diameter, $5.6-10.5 \mu$ or perhaps somewhat more in length; contents pale blue-green, slightly granular, pseudovacuoles not obvious; heterocysts terminal at both ends of the trichome, oval, little flattened at the point of contact with the trichome, and granule not evident, 3.7 to more commonly $5.1-(6 . I)-7.5 \mu$ in diameter, 4.5 to more commonly $6.0-(8.3)-9.6 \mu$ long (ratio I : I.35), pale straw-colored to colorless; spores intercalary, not seen close to the heterocysts, quickly isolated by fracture of the filament on one or both sides of the oval spore, 8.I-9.7 $\mu$ in diameter, I2.2-I6.2 $\mu$ long, wall moderately thick, straw-colored, apparently smooth.

This plant falls into the group with $A$. Arnoldii, A. circularis and A. Elenkinii, as did the last. From $A$. Arnoldii, with subspherical cells, it is obviously quite distinct. The revised description of $A$. circularis comes closer, but in that species the cells are rounded-cylindrical and 
narrower than the present, which has barrel-shaped cells 20 percent wider than those of $A$. circularis, and heterocysts considerably longer. On the whole, by far the closest resemblance is with $A$. Elenkinii, for the cell shape corresponds well, although $A$. luzonensis is larger; however, the heterocysts of the new plant are oval while those of $A$. Elenkinii are described as nearly spherical, and the spores are also relatively longer. With the marked heterocyst difference, and with considerable differences in vegetative cells and spores, and apparently in the color of masses of the plant, it seems best to describe the Philippine plant as a new species; but should other forms be found differing in various degrees, as have been found for A. Arnoldii, and connecting this plant with $A$. Elenkinii, it would then eventually be regarded as a geographical form of that plant.

\section{Descriptive Key to the Genus Anabaenopsis}

I. Heterocysts elongated. 2

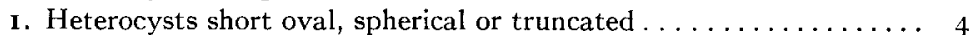

2. Heterocysts straight; trichomes straight or sparingly coiled ..... 3

2. Heterocysts curved, tapered, 2.6-3.8 $\mu \times 7.5^{-1} 3.2 \mu$; trichomes I.9$3.8 \mu$ diam., in long coils or tangled . . . . . . . . . . .

3. Trichomes $2.4-2.6 \mu$ diam.; heterocysts $2.0-3.0 \mu \times 5.0-6.0 \mu$, elliptical

A. philippinensis

3. Trichomes $2.5^{-4} .0 \mu$ diam.; heterocysts $2.0-2.5 \mu \times 5.0-7.0 \mu$, tapered

4. Cells of trichome at full growth much longer than broad . . . . . . .

4. Cells of trichome subspherical or compressed, seldom longer than

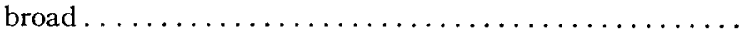

A. tanganyikae

A. Raciborskii

5

A. Arnoldii, incl.:

a. Heterocysts $5.8-9.2 \mu \times 8-$ I0 $\mu$; trichomes $6.5-9 \mu$; spores $\mathrm{I} 0.4^{-\mathrm{II}} .5 \mu \times \mathrm{II} .5^{-\mathrm{I}} 4.5 \mu \ldots \ldots \ldots \ldots \ldots$ Russian type

$b$. Heterocysts smaller; trichomes $5^{-8 \mu}$; spores $12-I 4 \mu$ $\times \mathrm{I} 6-\mathrm{I} 8 \mu \ldots \ldots \ldots \ldots \ldots \ldots \ldots$ Javanese form

c. Heterocysts slightly larger, $6.6-10.3 \mu \times 8.5-10.3 \mu$; trichomes $7.1-8.5 \mu$ diam. . . . . . . . frican form

d. Heterocysts $5.6-9.8 \mu \times 7.5-9.4 \mu$; trichome $7.5-9.4 \mu$; spores $8-12 \mu \times 12-16 \mu \ldots \ldots \ldots \ldots \ldots \ldots$ Philippine form

5. Trichome generally straight, 2.2-3.8 $\mu$ diam., cells about $3-4$ diam.

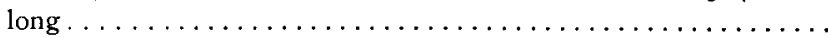

5. Trichome generally strongly arcuate to spiral, cells shorter . . . . . .

6. Cells rounded-cylindrical, $4.7-6.5 \mu$ diam.; heterocysts $5.6-7.5 \mu \times$

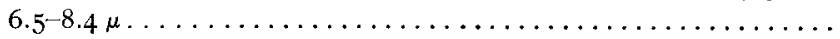

6. Cells barrel-shaped $\ldots \ldots \ldots \ldots \ldots \ldots \ldots \ldots \ldots \ldots \ldots \ldots \ldots$

7. Trichomes 4.6-5.7 $\mu$ diam.; heterocysts 4.6-6.7 $\mu$ diam., spherical; plant mass blackish-brown . . . . . . . . . . . . .

7. Trichomes $5.2-7.5 \mu$ diam.; heterocysts $5.1-7.5 \mu \times 6.09 .6 \mu$, oval. .

\section{A. Cunningtonii}

\author{
6
}

A. circularis

7

A. Elenkinii

A. Iuzonensis

\section{Diagnoses of New Species}

Anabaenopsis Cunningtonii n.sp. (Pl. XXXIX, figs. I-4).

Trichomata brevia, I IO-333 $\mu$ (plerumque circiter I65 $\mu$ ) longa, stricta vel raro curvata, $2.2-3.8 \mu$ diam. (plerumque $3.6 \mu$ ); cellulis cylindricis vel medio subdistensis, apice rotundatis compressione mutua modice planatis, plerumque ca. II.I $\mu$ longa, maximis ante divisionem I6.4 $\mu$, intus colore nondescriptis, textura paululo granulatis; heterocystibus utroque binis 
terminalibus ovoideis vel subovoideis, a cellulis adjacentibus modice planatis, plerumque granulo visibili praeditis, diam. $4.7-6.6 \mu$ (saepe $5.8 \mu$ ), 6.6-I0.3 $\mu$ (saepe $7.9 \mu$ ) longis, mature trichomata cito in segmenta separantibus; sporis ignotis.-Specimen typicum ex Lacu Tanganyika, Africa (W. A. Cunnington), in herb. auctor, et Univ. Mich.

Anabaenopsis luzonensis n.sp. (Pl. XL, figs. 8-I5).

Trichomata $5.2-7.5 \mu$ (plerumque $6.4 \mu$ ) diam., brevia, interdum stricta vel curvata, saepissime spiralia vel helicoidia, I-2-voluta, volutis $28-45 \mu$ diam., saepe inter se ex heterocystibus nondum separantibus helices compositas irregulariter paucivolutas formantia; cellulis media parte distensis, utroque ad septum versus terunciatim angustatis, 5.6-10.5 $\mu$ longis, intus pallide cyaneoviridibus, paululo granulatis, absque pseudovacuolis; heterocystibus utroque terminalibus ovoideis, ad cellulas adjacentes vix planatis haud granulatis, diam. 5.I-7.5 $\mu$ (rarissime 3.7, saepissime 6.I $\mu$ ), 6.0-9.6 $\mu$ longis (plerumque $8.3 \mu$ ), pallide stramineis vel decoloratis; sporis $8.1-9.7 \mu$ diam., I 2.2-I6.2 $\mu$ longis, intercalaribus nec prope heterocystes obviis, cito trichomatis fractione liberatis, parietibus modice crassis, stramineis laevibus.-Specimen typicum ex Lacu Sampaloc, Provincia Laguna, Ins. Philippinensibus (E. Quisumbing).

Anabaenopsis philippinensis n.sp. (Pl. XL, figs. I-7).

Trichomata subcylindrica, I.9-3.8 $\mu$ diam. (plerumque $3.3 \mu$ ), elongata, spiraliter $8-\mathrm{I} 2$-voluta, volutis $\mathrm{I} 2-25 \mu$ diam., vel elongata plus minusve intricata pro parte spiralia; cellulis cylindricis apice vix vel haud quaquam constrictis ca. $6.6 \mu$ longis sed septis indistinctis, intus pallide cyaneoviridibus, paululo granulatis, absque pseudovacuolis; heterocystibus utroque terminalibus diam. 2.6-3.8 $\mu$ (plerumque $3.5 \mu$ ), 7.5-I $3.2 \mu$ (plerumque $9.4 \mu$ ) longis, rotundato-conicis fere ex basi ad apicem rotundatum angustatis, rectis vel curvatis, membrana pallide straminea tenui vix ad septum incrassata, absque granulo basellari; sporis nondum visis. Specimen typicum ex Lacu Sampaloc, Provincia Laguna, Ins. Philippinensibus (E. Quisumbing).

\section{SUMMARY}

An account is given of the results of a re-examination of a portion of the original plankton material from which G. S. West described certain Anabaenas upon which the genus Anabaenopsis has since been founded. One of his species (A.tanganyikae) was scantily represented and probably as he interpreted it. His other concept ( $A$. circularis) is to be viewed as three plants, Anabaenopsis circularis s.s., A. Arnoldii fa., and A. Cunningtonii n. sp., all of which are described. An account is then given of the examination of Philippine phytoplankton samples, in which three Anabaenopses were found. One of these is also a form of $A$. A rnoldii, to which species the geographically proximate Javanese $A$. A rnoldii var. javanica (Wolos.) is related. The other two are new species, $A$. philippinensis being related to $A$. Raciborskii and the other, $A$. luzonensis to $A$. Elenkinii. These are described, the interrelationships in the genus are discussed, and a descriptive key to the genus is given.

UNIVERSITY OF MICHIGAN, AnN Arbor, Michigan 

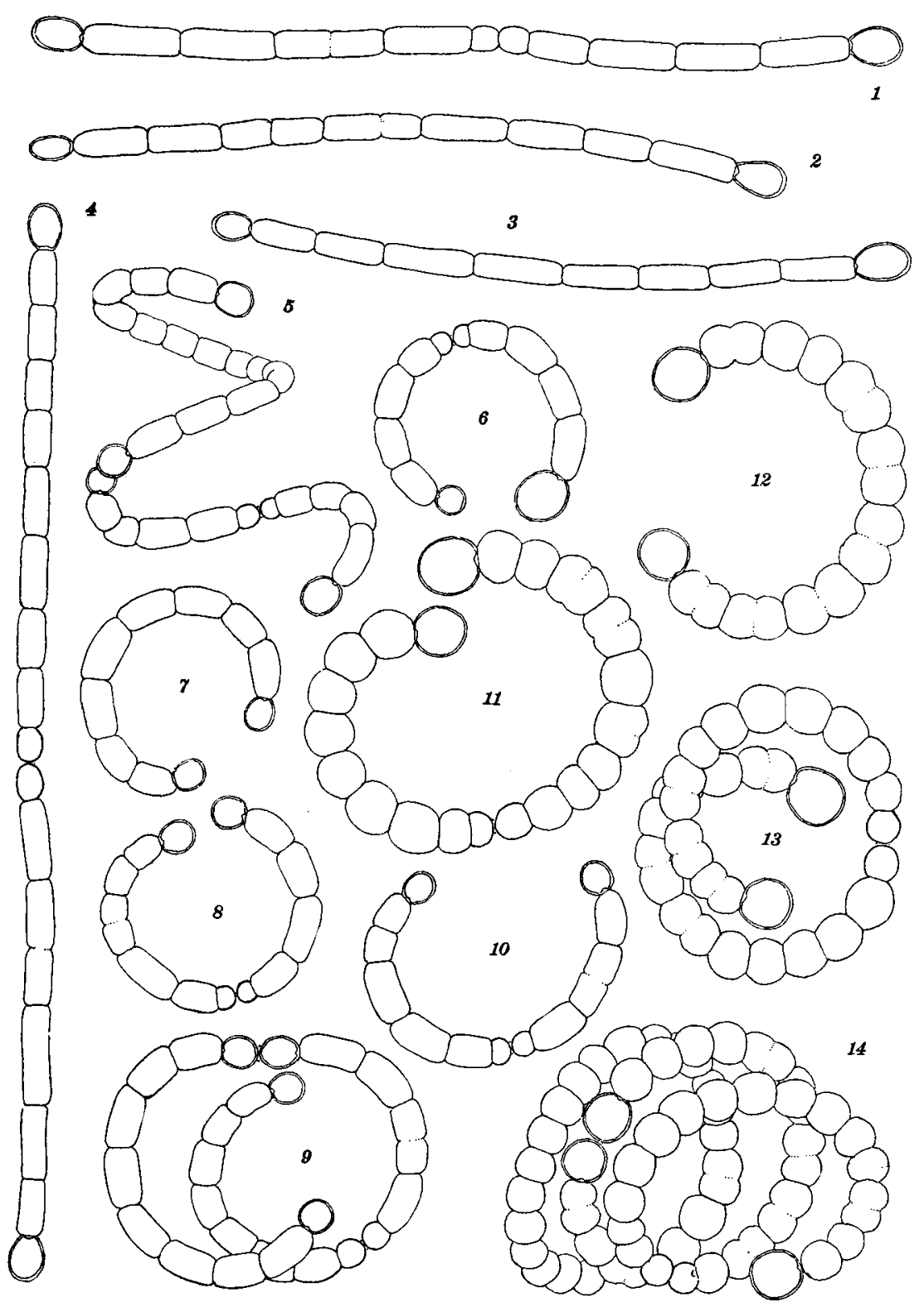

TAYlor: Anabaenopsis 


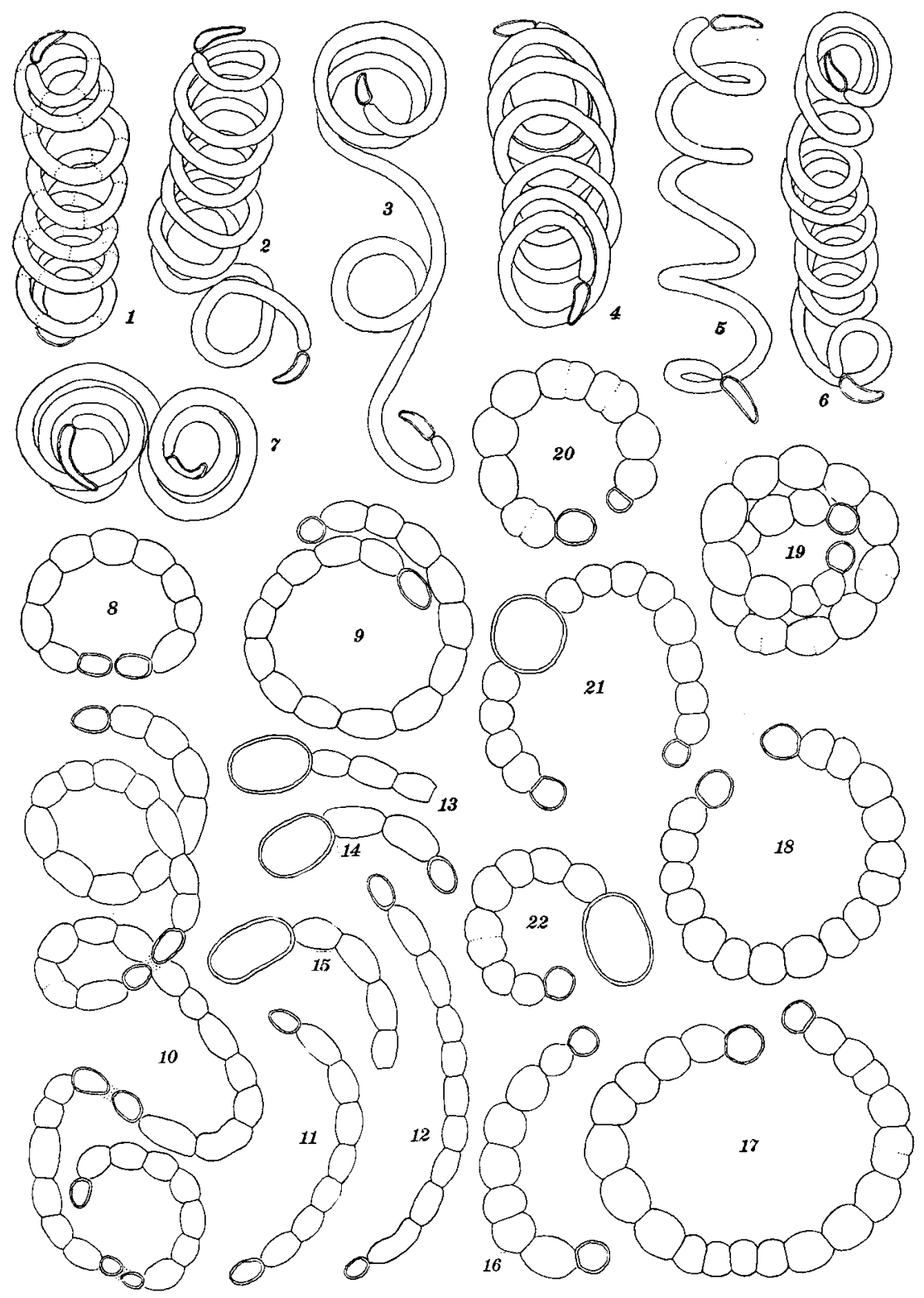

TAylor: Anabaenopsis 


\section{LITERATURE CITED}

I. Aptekarj, E. M. De nova Cyanophycearum specie Anabaenopsis A rnoldii mihi. Bot. Mat., Inst. Sporov. Rast. Glav. Bot. Sad U.S.S.R. 4 (4): 4I-55. 1926.

2. Drew, K. M. The occurrence of heterocysts and spores at both ends of the filament in the genus Cylindrospermum. Rev. Algol. 5: I43-I45. I930.

3. Elenkin, A. Neskolko slov povodu roda Anabaenopsis (Wołos.) Miller iz sizelenykh vodoroslei. Bot. Mat., Inst. Sporov. Rast. Glav. Bot. Sad U.S.S.R. 2: 73-78. 1923.

4. Fremy, P. Les Myxophycèes de l'Afrique Equatoriale Francaise. Archives Bot. 3 (Mem. 2): 508 pp., 362 fig. Caen, 1929 (I930).

5. Gonzales-Guerrero, P. El genero Anabaenopsis (Wołos.) V. Miller en España. Bol. R. Soc. Española Hist. Nat. 28: 357-359. 1928.

6. - Mas datos ficologicos de agua dulce. Bol. R. Soc. Española Hist. Nat. 28: 435-438. I928.

6a. - - Nuevos datos de plancton Hispano-Marroqui (agua dulce). Bol. R. Soc. Española Hist. Nat. 29: 25I-254. I929.

7. Miller, V. K sistematike roda Anabaena Bory. Russkii Arkh. Protistol. 2: II6-I26. I923.

8. Roll, J. Algues nouvelles, trouvèes dans le plancton de la riviere Dniepre. Ann. Protistol. I (4): 163-I66. 1928.

9. West, G. S. Report on the freshwater algae, including phytoplankton, of the Third Tanganyika Expedition, conducted by Dr. W. A. Cunnington 1904-5. Jour. Linn. Soc. Bot. 38: 81-197. 1907.

Jo. Woloszńyska, J. O glonach planktonovych niektórych jezior jawanskich, z uwzglednieniem glonów Sawy. Bull. Internat. Acad. Sci. Cracovie, Cl. Sci., Math. et Nat., B., Sci. Nat. I912: 649-709. 1912-13.

\section{DESCRIPTION OF PLATES}

\section{Plate XXXIX}

FIGs. I-4. Anabaenopsis Cunningtonii $(\times 740)$. Trichomes showing heterocysts, and intercalary pairs of developing heterocysts.

FIGS. 5-IO. Anabaenopsis circularis $(\times 740)$. Trichomes showing terminal heterocysts of various ages, and developing intercalary pairs.

FIGS. II-I4. Anabaenopsis Arnoldii (African form) ( $\times 740$ ). Trichomes showing intercalary and terminal heterocysts.

\section{Plate XL}

FIGs. I-7. Anabaenopsis philippinensis $(X 606)$. Trichomes showing heterocysts; cell wall limits partly indicated in figure $I$.

FIGs. 8-15. Anabaenopsis luzonensis $(\times 606)$. Trichomes showing heterocysts and (figs. 13-15) spores; figure Io shows association in chain of trichomes.

FIGs. 16-22. Anabaenopsis Arnoldii (Philippine form) $(\times 606)$. Trichomes showing heterocysts and (figs. 2I, 22) spores. 